\title{
Development and validation of an RNA- and DNA- based quantitative PCR assay for determination of Kudoa thyrsites infection levels in Atlantic salmon Salmo salar
}

\author{
Valerie A. Funk ${ }^{1, *}$, Monique Raap ${ }^{2}$, Ken Sojonky ${ }^{3}$, Simon Jones ${ }^{2}$, John Robinson ${ }^{3}$, \\ Christy Falkenberg ${ }^{2}$, Kristina M. Miller ${ }^{2}$ \\ ${ }^{1}$ BC Centre for Aquatic Health Sciences, 621 Island Highway, PO Box 277, Campbell River, British Columbia V9W 5B1, \\ Canada \\ ${ }^{2}$ Pacific Biological Station, Department of Fisheries and Oceans Canada, 3190 Hammond Bay Road, Nanaimo, \\ British Columbia V9T 6N7, Canada \\ ${ }^{3}$ Animal Health Centre, Ministry of Agriculture, Fisheries and Food, 1767 Angus Campbell Road, Abbotsford, \\ British Columbia V3G 2M3, Canada
}

\begin{abstract}
Quantitative PCR (QPCR) methods targeting the 18S rDNA gene (DNA QPCR) and cathepsin L mRNA (RNA QPCR) from Kudoa thyrsites (Gilchrist) were developed and compared with histology for determination of $K$. thyrsites infection levels in Atlantic salmon Salmo salar L. Both QPCR tests were specific, reproducible and sensitive down to 3 copies. DNA QPCR was able to detect lower $K$. thyrsites infection levels than those detected by RNA QPCR and histology. The higher sensitivity of the DNA-based test compared with the RNA-based test appeared to be biological in nature and suggested that when infection levels were low, there were fewer copies of cathepsin L mRNA than 18S rDNA genes. However, all 3 diagnostic methods were highly correlated. Regression analyses comparing DNA QPCR and histology data from 2 distinct groups of fish showed that the relationship between these 2 diagnostic methods was reproducible. A logistic regression analysis comparing diagnostic data with a visual assessment of post-mortem flesh quality indicated that histology was the single best predictor of flesh quality, followed by DNA QPCR and then RNA QPCR.
\end{abstract}

KEY WORDS: Kudoa thyrsites · Atlantic salmon · Diagnostics · QPCR · RNA test · DNA test · Histology $\cdot$ Myoliquefaction

\section{INTRODUCTION}

Kudoa thyrsites (Gilchrist) (Myxozoa: Myxosporea) is an intracellular parasite capable of infecting many marine teleosts (reviewed by Moran et al. 1999a, Moran \& Kent 1999). Kudoa thyrsites plasmodia grow within myocytes and become filled with myxospores. The life-cycle of $K$. thyrsites has not yet been elucidated but probably includes an alternative annelid host similar to that of many freshwater myxosporean parasites (Wolf \& Markiw 1984, Kent et al. 2001).

Within the live teleost host, Kudoa thyrsites infections are not associated with a disease. However, fol- lowing death, infected somatic muscle tissue is proteolytically digested, and the degree of 'myoliquefaction' has been correlated to the severity of $K$. thyrsites infections

(St-Hilaire et al. 1997a, Dawson-Coates et al. 2003). Post-mortem tissue damage associated with $K$. thyrsites infections has resulted in an economic cost to Atlantic salmon producers in British Columbia (Canada) estimated at 50 million Canadian dollars in lost revenues in 2002 alone.

The control of Kudoa thyrsites infections in farmed populations of Atlantic salmon poses many challenges. Without knowledge of the infective actinosporean 
stage, it is difficult to discern biological and environmental factors affecting parasite abundance in the environment and, ultimately, the risk to farmed salmon. Efforts have been made to understand factors affecting the susceptibility of Atlantic salmon to $K$. thyrsites infections (Funk et al. 2004), but in the absence of a challenge model this type of work is also difficult. At present, management of the infection relies on site selection, optimising smolt quality and monitoring stock for the presence of myxospores. Therefore, development of an efficacious vaccine is arguably the most promising method with which to minimize the impacts of $K$. thyrsites on fillet quality. To facilitate vaccine development, improved diagnostics are required for measuring $K$. thyrsites infection levels.

Kudoa thyrsites infection levels are routinely determined through examination of stained histological sections, and this measure has been shown to be a relatively good predictor for post-mortem flesh quality (Dawson-Coates et al. 2003). However, histology lacks the sensitivity required to quantify low-level infections and requires a minimum seawater exposure period of 900 degree days before plasmodia can be detected reliably (Moran et al. 1999b). Therefore, histological methods as a measure of vaccine efficacy preclude evaluation of low infection levels and prevent rapid evaluation of newly developed vaccine candidates.

Standard PCR is routinely used to detect the Kudoa thyrsites small subunit ribosomal DNA (18S rDNA) (Hervio et al. 1997) and has detected K. thyrsites in smolts after sea water exposures of only 350 degree days (V. Funk unpubl. data). However, while this technique is highly sensitive and can provide accurate information on the presence or absence of the parasite, it does not quantify the level of infection and, therefore, cannot be used as a measure of vaccine efficacy. The present study was undertaken to employ the $18 \mathrm{~S}$ rDNA sequence for the development of a quantitative PCR (QPCR) test for the evaluation of $K$. thyrsites infection levels.

In addition to the DNA-based test, an RNA-based test was also developed that targeted the mRNA of the parasite-derived cathepsin $\mathrm{L}$ peptidase thought to play a significant role in post-mortem myoliquefaction $(\mathrm{V}$. Funk et al. unpubl. data). QPCR data were compared with histology results and all 3 diagnostic tests were evaluated as predictive measures of post-mortem flesh quality.

\section{MATERIALS AND METHODS}

Experimental fish, tissue sampling and histology. Group 1. Intrafish variability: Atlantic salmon $(\mathrm{n}=98)$ (Group 1) ranging in size from 0.4 to $4.0 \mathrm{~kg}$ were

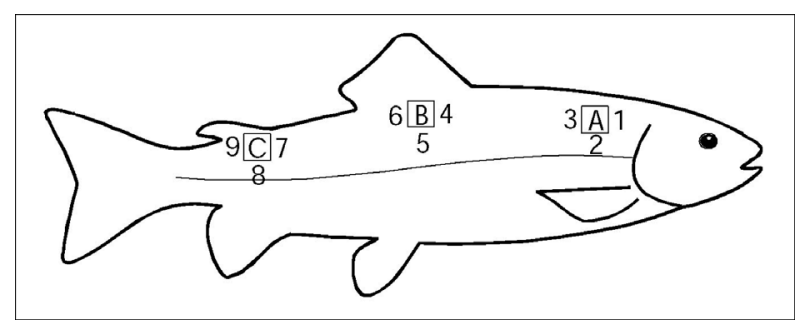

Fig. 1. Salmo salar. Sites where muscle tissue was removed for QPCR and histological analyses. A, B and C correspond to areas where muscle blocks were removed for histology; numbers 1 to 9 indicate locations where muscle plugs were removed for extraction of RNA and DNA

exposed to sea water at the Pacific Biological Station, Departure Bay, Nanaimo, British Columbia, Canada for a minimum of 1200 degree days, and sampled to determine Kudoa thyrsites infection levels by the QPCR methods and histology. Sea water in Departure Bay contains the actinospore stage of $K$. thyrsites, which causes infections in susceptible salmonids (Moran et al. 1999b). Separate muscle samples were obtained for histological assessment and QPCR. Muscle plugs for QPCR analyses were taken using biopsy punches (5 mm diameter, Acuderm) from 9 locations (Fig. 1). Muscle plugs were cut into pieces not exceeding $3 \mathrm{~mm}$ in length and placed directly into RNAlater (Qiagen). Samples were stored at $4^{\circ} \mathrm{C}$ overnight and at $-20^{\circ} \mathrm{C}$ thereafter.

Muscle blocks for histological assessment were removed from 3 locations along the epaxial muscle band: anterior, mid and posterior (Fig. 1: A-C) and placed immediately into Davidson's solution. Thin sections $(5 \mu \mathrm{m})$ of fixed muscle tissue cut on the cross-section were prepared using standard histological techniques and stained with haematoxylin and eosin (H\&E). Thin sections were prepared from 3 depths within each of the 3 muscle blocks and examined using $160 \times$ magnification. Infection intensity was determined by counting plasmodia in a minimum of 50 fields of view (FOV) for each section, and an average of $442 \pm$ 66 (SD) FOV, which corresponded to $416 \mathrm{~mm}^{2}$ of crosssectional area, were examined for each fish. The infection intensity was expressed as the number of plasmodia per $\mathrm{mm}^{2}$.

Muscle samples taken from fish in Group 1 were used to assess the intrafish variability in the relative amount of cathepsin L mRNA and 18S rDNA. Histology results were used to select 12 fish displaying a range of Kudoa thyrsites infection levels that included infection levels ranging from a total of 0 to 404 plasmodia counted in all FOV, as well as fish showing variation in the number of plasmodia counted in the 3 muscle blocks. RNA and DNA were extracted from all 
9 intrafish samples and used for quantification of cathepsin L mRNA and 18S rDNA, respectively. However, DNA from 1 muscle sample from Fish 99 and RNA from 3 plugs from Fish 6 were utilized during test development, so that the total number of intrafish samples for DNA QPCR and RNA QPCR was 107 and 105, respectively (see Table 3). RNA and DNA QPCR data from individual plugs were compared with the average histology data calculated from the muscle block closest in proximity so that QPCR data from Plugs 1, 2 and 3 were compared with histology data from Block A (Fig. 1). The RNA and DNA samples in the remaining 86 fish were used to investigate the correlations among diagnostic methods.

Groups 1, 2 and 3. Correlation among diagnostics and comparisons with visual evaluation of fillet quality: The second group of Atlantic salmon ( $\mathrm{n}=150$ ) (Group 2) sampled for Kudoa thyrsites infection levels had been exposed to sea water for 8 mo (2600 degree days) and had an average weight of $442 \pm 96 \mathrm{~g}$. Muscle blocks corresponding to A, B and C (Fig. 1) were removed and fixed in Davidson's solution for the determination of parasites in histological thin sections. One thin section was prepared from each block, which allowed the viewing of approximately 60 FOV. Therefore, average infection levels for individual fish were based on the number of plasmodia in 180 FOV, corresponding to $177 \mathrm{~mm}^{2}$.

Separate pieces of muscle tissue (20 to $40 \mathrm{mg}$ each) were removed from fillet locations 1, 4 and 7 (Fig. 1), pooled and immediately frozen in liquid nitrogen. Separate pooled samples were taken for RNA and DNA extractions.

All muscle samples were removed from the right side of the fish, allowing the left fillet to be removed for visual evaluation of damage owing to Kudoa thyrsites. Fillets were evaluated $7 \mathrm{~d}$ post-mortem and categorized based on the level of parasite-induced proteolytic digestion or 'myoliquefaction.' The categories were defined as follows: 1 = no visible signs of damage; $2=1$ to 20 pits indicative of proteolytic digestion; $3=>20$ pits with pits occurring as discrete entities; $4=$ pits beginning to run together so that they were no longer discrete; 5 = pits no longer evident owing to excessive liquefaction; $6=$ muscle tissue flowed off the skin owing to excessive proteolysis.

A third group of Atlantic salmon ( $\mathrm{n}=362$ ) with an average weight of $170 \pm 38 \mathrm{~g}$ was sampled and Kudoa thyrsites infection levels were assessed via DNA QPCR and histology in the same manner as fish in Group 2.

The relative amount of cathepsin L mRNA and $18 \mathrm{~S}$ rDNA was determined from RNA and DNA extracted from a pool of muscle tissue taken from Plugs 1, 4 and 7. RNA and DNA QPCR data from fish in Group $1(\mathrm{n}=86)$ and Group 2 ( $\mathrm{n}=150)$ were correlated to the average histology value calculated for each fish. Only DNA QPCR results were correlated to histology values for fish in Group 3. RNA and DNA QPCR results were also correlated. All values were transformed to $\log _{10}$ prior to correlation analyses, and zero values were included as $0.5 \times$ minimum detectable value for each diagnostic.

RNA and DNA extractions. Group 1: RNA and DNA were extracted from the same piece of muscle tissue or pool of muscle samples for all samples originating from fish in Group 1. RNA was extracted from muscle samples (<100 mg) using Trizol (Sigma) following the manufacturer's instructions. Precipitated and washed RNA was dissolved in 30 to $50 \mu$ l RNAse-free water. A $2 \mu \mathrm{l}$ aliquot was diluted 10-fold, quantified using a GeneQuant Pro spectrophotometer (Biochrom), run on a $1.5 \%$ agarose gel (60 min at $110 \mathrm{~V}$ ) and stained with SYBR Safe (Invitrogen Life Technologies) to assess quality by the ratio of $28 \mathrm{~S}$ to $18 \mathrm{~S}$ rRNA band intensities, which should be close to 2:1 for good quality RNA.

DNA was precipitated from the Trizol phase using ice-cold $95 \%$ ethanol (600 $\mu \mathrm{l})$ and the precipitate transferred into $70 \%$ ethanol $(1.0 \mathrm{ml})$. Following 3 washing steps using $70 \%$ ethanol, the precipitate was resuspended in $900 \mu \mathrm{l}$ ATL buffer (DNeasy kit, Qiagen) with $90 \mu$ l Proteinase $\mathrm{K}$ and digested overnight at $56^{\circ} \mathrm{C}$. A $200 \mu \mathrm{l}$ aliquot was put through a DNeasy column following the manufacturer's instructions and eluted in $70 \mu \mathrm{l}$ DNase-free water.

Groups 2 and 3: RNA was extracted from samples (ca. 100 mg) using 'MagMAX-96 for Microarrays' extraction kit (Ambion) on a Biomek NX liquid handler (Beckman Coulter). The RNA was eluted in $50 \mu \mathrm{l}$ elution buffer, quantified spectrophotometrically using a DTX 880 Multimode Detector (Beckman Coulter) and finally normalized to $80 \mathrm{ng} \mathrm{ul}^{-1}$.

DNA was extracted from muscle samples (approx. $100 \mathrm{mg}$ ) using DNeasy kits (Qiagen) as per manufacturer's instructions but using a $400 \mu \mathrm{l}$ volume for proteinase $\mathrm{K}$ digestion with an overnight incubation period at $55^{\circ} \mathrm{C}$. Only $200 \mu \mathrm{l}$ of the digest was loaded onto the spin columns, and eluted DNA was normalized to $50 \mathrm{ng} \mathrm{Hl}^{-1}$.

cDNA synthesis. Prior to cDNA synthesis, purified RNA was treated to remove contaminating DNA and Rnases. In a reaction volume of $9 \mu \mathrm{l}$, RNA (1 $\mu \mathrm{g})$ was incubated at room temperature for $15 \mathrm{~min}$ in the presence of Rnase-OUT (20 U), Dnase amplification grade (0.5 U) and Dnase reaction buffer (Invitrogen). Dnase was inactivated by incubation with $2.5 \mathrm{mM}$ EDTA for $10 \mathrm{~min}$ at $65^{\circ} \mathrm{C}$. Anchored oligo dT $(4.5 \mu \mathrm{M})$ was annealed to template mRNA by incubating at $70^{\circ} \mathrm{C}$ for $5 \mathrm{~min}$ followed by 2 min on ice. cDNA synthesis occurred in a reaction volume of $19.5 \mu \mathrm{l}$ containing $0.77 \mathrm{mM}$ dNTPs, 20 units of Rnase-OUT, $5.1 \mathrm{mM}$ DTT, $1 \times 1$ st Strand B Buffer and 200 units of Superscript III (Invitrogen). Syn- 
thesis was carried out at $43^{\circ} \mathrm{C}$ for $2 \mathrm{~h}$. Superscript III was then denatured by heating to $70^{\circ} \mathrm{C}$ for $15 \mathrm{~min}$. Residual RNA was destroyed using $5 \mu \mathrm{g}$ Rnase A (United States Biochemical Corporation) and 1 unit Rnase $\mathrm{H}$ (Invitrogen) with incubations at $37^{\circ} \mathrm{C}$ for $20 \mathrm{~min}$ followed by $65^{\circ} \mathrm{C}$ for $20 \mathrm{~min}$. All cDNA samples were diluted to a final volume of $100 \mu \mathrm{l}$ with double distilled water and stored at $-20^{\circ} \mathrm{C}$. With each set of cDNA synthesis, reaction controls containing RNA but lacking reverse transcriptase and controls lacking RNA but containing reverse transcriptase were included.

The optimal amount of starting RNA for cDNA synthesis was determined to ensure that reagents were not limiting. cDNA synthesis was carried out using 1 to $4 \mu \mathrm{g}$ RNA, and resulting cycle threshold C(T) values using the acidic ribosomal phosphoprotein (ARP) primers and probe showed cDNA synthesis to become limited at RNA quantities of $\geq 3 \mu \mathrm{g}$ (data not shown). Therefore, the starting amount of RNA for cDNA synthesis was standardized to $1 \mu \mathrm{g}$. This quantity of RNA resulted in $\mathrm{C}(\mathrm{T})$ values of approximately 20 for the reference gene (ARP).

Assays for QPCR. Cathepsin L: Kudoa thrysites cathepsin L cDNA (GenBank accession numbers DQ995499 to DQ995507) was sequenced (1166 bp), revealing a putative protein sequence 313 amino acids in length (V. Funk et al. unpubl. data). From the cDNA sequence, primer and probe sets were designed using Beacon Designer 3 software (Premier Biosoft) that amplified a $164 \mathrm{bp}$ region (Table 1). The gene-specific dual-labeled probe was conjugated with 5' FAM and 3' TAMRA (Integrated DNA Technologies).

The relative number of cathepsin L mRNA transcripts was normalized against Salmo salar acidic ribo- somal phosphoprotein P0 (ARP) (Pierce et al. 2004, Purcell et al. 2004). Amplification and quantification of ARP generated a 106 bp product (Table 1).

Group 1: Cathepsin L QPCR was carried out in a $12 \mu \mathrm{l}$ reaction volume containing $2 \mu \mathrm{l} \mathrm{cDNA}, 1 \times$ Platinum Quantitative PCR Supermix-UDG (Invitrogen), $300 \mathrm{nM}$ of forward and reverse primers for cathepsin L or ARP and $300 \mathrm{nM}$ of the probes. Reactions were carried out in a 96-well format using an MJ Opticon 1 thermal cycler (BioRad Laboratories). All samples were run in triplicate and each plate contained RNA, reverse transcriptase and template negative controls. The amplification profile was $50^{\circ} \mathrm{C}$ for 2 min and $95^{\circ} \mathrm{C}$ for $2 \mathrm{~min}$, then 45 cycles of $95^{\circ} \mathrm{C}$ for $15 \mathrm{~s}$, and $61^{\circ} \mathrm{C}$ for $1 \mathrm{~min}$. The $\mathrm{C}(\mathrm{T})$ value was defined as 20 times the standard deviation of the baseline fluorescent signal.

Group 2: Cathepsin L QPCR was carried using 384well plates and a reaction volume of $20 \mu$ with $2 \mu \mathrm{l}$ cDNA. Primers and probes were added to a final concentration of 800 and $250 \mathrm{nM}$, respectively, in $2 \times$ TaqMan ${ }^{\circledR}$ Universal PCR Master Mix (Applied Biosystems). Amplification was carried out in an ABI 7900 using the same profile described above. All samples were run in duplicate and each plate contained RNA, reverse transcriptase and template negative controls as well as clone standards carried out in triplicate.

$18 S$ rDNA: Group 1: TaqMan ${ }^{\circledR}$ primer and probe sequences for Kudoa thyrsites 18S rDNA (target, 82 bp product) and Salmo salar cytochrome B (cyt B) (reference, $69 \mathrm{bp}$ product) genes were designed using Primer Express version 3.0 (Applied Biosystems) (Table 1).

QPCR of 18S rDNA from fish in Group 1 was carried out in $25 \mu \mathrm{l}$ reaction volume containing 20 ng DNA, $1 \times$

Table 1. Sequences of primers and probes for target and reference genes used in RNA and DNA QPCR tests. F: forward primer; $\mathrm{R}$ : reverse primer; $T_{\mathrm{m}}$ : melting temperature calculated by Primer Express; ARP: acidic ribosomal phosphoprotein; cyt B: cytochrome B. For details on Groups 1-3 see 'Materials and methods'

\begin{tabular}{|c|c|c|c|c|}
\hline Target & Primer & Sequence $\left(5^{\prime}-3^{\prime}\right)$ & $\begin{array}{c}T_{\mathrm{m}} \\
\left({ }^{\circ} \mathrm{C}\right)\end{array}$ & $\begin{array}{c}\text { GenBank } \\
\text { accession no. }\end{array}$ \\
\hline Cathepsin L & $\begin{array}{c}\mathrm{F} \\
\mathrm{R} \\
\text { Probe }\end{array}$ & $\begin{array}{l}\text { AAAGACATCAAATCGACTCTACCT } \\
\text { CTAAAGTTGACCAATTCTCCAGTT } \\
\text { (FAM)-CATACGCCGACTCGATTGCCCCG-(TAMRA) }\end{array}$ & $\begin{array}{c}54.3 \\
54.7 \\
78\end{array}$ & DQ995499 \\
\hline ARP & $\begin{array}{c}\mathrm{F} \\
\mathrm{R} \\
\text { Probe }\end{array}$ & $\begin{array}{l}\text { GAAAATCATCCAATTGCTGGATG } \\
\text { CTTCCCACGCAAGGACAGA } \\
\text { (FAM)-CTATCCCAAATGTTTCATTGTCGGCGC-(TAMRA) }\end{array}$ & $\begin{array}{c}59.3 \\
58.4 \\
75\end{array}$ & AY505012 \\
\hline 18S rDNA & $\begin{array}{l}\mathrm{F} \\
\mathrm{R}\end{array}$ & $\begin{array}{l}\text { TGGCGGCCAAATCTAGGTT } \\
\text { GACCGCACACAAGAAGTTAATCC }\end{array}$ & $\begin{array}{l}59.1 \\
58.7\end{array}$ & AF031412 \\
\hline $\begin{array}{l}\text { Group } 1 \\
\text { Groups } 2 \text { \& } 3\end{array}$ & $\begin{array}{l}\text { Probe } \\
\text { Probe }\end{array}$ & $\begin{array}{l}\text { (FAM)-TATCGCGAGAGCCGC-(MGBNFQ) } \\
\text { (VIC)-TATCGCGAGAGCCGC-(MGBNFQ) }\end{array}$ & 69.9 & \\
\hline Cyt B & $\begin{array}{c}\mathrm{F} \\
\mathrm{R} \\
\text { Probe }\end{array}$ & $\begin{array}{l}\text { GGCCAACCTCCGAAAAACTC } \\
\text { GGTGCTGGGAGATCGACTAGTG } \\
\text { (FAM)-CTCCTAAAAATTGCTAATGAC-(MGBNFQ) }\end{array}$ & $\begin{array}{l}59.5 \\
59.7 \\
69.1\end{array}$ & AJ314567 \\
\hline
\end{tabular}


Applied Biosystems TaqMan ${ }^{\circledR}$ Universal PCR Master Mix, $800 \mathrm{nM}$ of forward and reverse primers for $18 \mathrm{~S}$ rDNA or cyt B and $250 \mathrm{nM}$ of the probes (Table 1). Reactions were carried out in a 96-well format using an Applied Biosystems SDS7000. All samples were run in triplicate and each plate contained a template negative control. The amplification profile was $50^{\circ} \mathrm{C}$ for $2 \mathrm{~min}$ and $95^{\circ} \mathrm{C}$ for $10 \mathrm{~min}$, then 40 cycles of $95^{\circ} \mathrm{C}$ for $15 \mathrm{~s}$, and $60^{\circ} \mathrm{C}$ for $1 \mathrm{~min}$. The $\mathrm{C}(\mathrm{T})$ value was defined as 20 times the standard deviation of the baseline fluorescent signal.

Groups 2 and 3: Quantification of target and reference genes in samples from fish in Groups 2 and 3 were multiplexed using a VIC-labeled probe for the target gene and a FAM-labeled probe for the reference gene (Table 1). QPCR reactions were carried out using 384-well plates with a $20 \mu \mathrm{l}$ reaction volume, which contained $270 \mathrm{ng}$ genomic DNA. The amount of genomic DNA was increased to $270 \mathrm{ng}$ from the $20 \mathrm{ng}$ used in the analysis of samples from Group 1 so that the $\mathrm{C}(\mathrm{T})$ values for the reference gene would be lower, thus increasing test sensitivity. Primers for the target and reference genes were added to a final concentration of $800 \mathrm{nM}$ and $94 \mathrm{nM}$, respectively, and both probes were used at a concentration of $250 \mathrm{nM}$ in $2 \times$ Platinum Quantitative PCR Supermix-UDG (Invitrogen). The amplification profile was $50^{\circ} \mathrm{C}$ for $2 \mathrm{~min}$, $95^{\circ} \mathrm{C}$ for $2 \mathrm{~min}$, then 45 cycles of $95^{\circ} \mathrm{C}$ for $15 \mathrm{~s}$, and $60^{\circ} \mathrm{C}$ for $1 \mathrm{~min}$. All samples were amplified in triplicate using an Applied Biosystems 7900 with no template controls and clone 18S rDNA standards on every plate.

Primer specificity. Cathepsin L and 18S rDNA primers were tested for specificity against DNA from a variety of myxozoans. DNA from Myxobolus cerebralis, Kudoa minauriculata, K. hypoepicardialis, Ceratomyxa shasta, Henneguya salminicola and Sphaerospora oncorhynchi were used to assess primer specificity. The primers 18E and Myxgen2r (Hillis \& Dixon 1991, Kent et al. 2000) were used to ensure the presence of myxozoan DNA.

Standard PCRs using both cathepsin L and $18 \mathrm{~S}$ rDNA primers were carried out in $25 \mu$ reaction volume containing approximately $100 \mathrm{ng}$ genomic DNA, $300 \mathrm{nM}$ of each primer, 1.75 U Taq polymerase (Qiagen), $1 \times$ Qiagen buffer, and $300 \mu \mathrm{M}$ dNTPs. PCR cycling conditions for MJ Research PTC100 thermocyclers (BioRad Laboratories) included a $3 \mathrm{~min}$ hot start followed by 35 cycles of $94^{\circ} \mathrm{C}$ for $1 \mathrm{~min}, 54^{\circ} \mathrm{C}$ for $1 \mathrm{~min}$ and $68^{\circ} \mathrm{C}$ for $1 \mathrm{~min}$, with a final extension at $68^{\circ} \mathrm{C}$ for $10 \mathrm{~min}$. Amplified products were run on $1.5 \%$ agarose gels and visualized by SYBR Safe DNA gel stain (Molecular Probes, Invitrogen).

Standard design for RNA and DNA QPCR. A nearly full length Kudoa thrysites cathepsin L cDNA sequence (948 bp) and the ARP amplified product (106 bp) were cloned using a TOPO TA cloning kit
(Invitrogen) following the manufacturer's protocols and confirmed by sequencing using Applied Biosystem's Big Dye Terminator V3.1 kit and an Applied Biosystems 377 sequencer. The full-length cathepsin L and ARP plasmids were $4879 \mathrm{bp}$ and $4037 \mathrm{bp}$, respectively, corresponding to molecular weights of $3.22 \times 10^{6}$ and $2.66 \times 10^{6} \mathrm{~g} \mathrm{~mole}^{-1}$ (Yin et al. 2001). The copy number per $\mu \mathrm{g}$ DNA was calculated as $1.87 \times 10^{11}$ and $2.26 \times 10^{11}$, respectively. DNA concentration of the HindIII-linearized plasmids (New England Biolabs) was determined by spectrophotometer (GeneQuant Pro, Biochrom). To ensure similar amplification efficiencies from target and reference clones and to determine the range of linearity, standard curves consisting of 10 -fold serial dilutions and spanning 6 orders of magnitude ( 3 to $10^{6}$ copies) were generated from both clones. The cathepsin L clone alone was then used to generate a standard curve (3 to 300000 copies) on each 96-well plate.

To confirm the absence of inhibitors co-purifying with RNA from tissue samples, relative standard curves for both cathepsin and ARP were generated using a series of diluted RNA and cDNA from a sample (Fish 82). The efficiencies calculated were similar to those generated with the clones (data not shown).

Standards for Kudoa thyrsites $18 \mathrm{~S}$ rDNA and Salmo salar cyt B PCR products were made as described above, resulting in plasmids of 4013 and 4000 bp in length, respectively. Molecular weights of plasmids containing 18S rDNA and cyt B inserts were calculated as $2.65 \times 10^{6}$ and $2.64 \times 10^{6}$, respectively, corresponding to $2.27 \times 10^{11}$ and $2.28 \times 10^{11}$ copies $\mu$ DNA $^{-1}$ (Yin et al. 2001). DNA concentrations were determined using an LKB Ultrospec III (Amersham Pharmacia Biotech) and standard curves generated as described above. Relative standard curves were generated for both 18S rDNA and cytochrome B using DNA (1 to 32 ng DNA) from Subsample 8 from Fish 1 and Subsample 5 from Fish 6.

Reproducibility. Assay variability for cathepsin L mRNA QPCR was assessed by determining the relative cathepsin L mRNA copy number in Fish 82 on different days at 6 different dilutions of cDNA and using 6 different quantities of RNA for cDNA synthesis.

Assay variability for $18 \mathrm{~S}$ rDNA was assessed by determining the relative copy number in 14 samples amplified on different days. The relative $18 \mathrm{~S}$ rDNA copy number was also determined for 2 different samples using serial dilutions of DNA (1 to $32 \mathrm{ng}$ ).

Data analysis. Copy numbers of the target and reference genes were determined by standard curve quantitation. The relative cathepsin copy number was determined by dividing the number of target copies by the number of reference copies (reviewed by Ginzinger 2002). 
The relative target copy number was also determined by 'relative quantitation', where $\Delta \mathrm{C}(\mathrm{T})$ (target minus the reference) is the exponent of base 2 (i.e. relative copy number $=2^{-\Delta \mathrm{C}(\mathrm{T})}$, Ginzinger 2002). Relative values for the number of target sequences calculated by the 2 methods were compared.

The variation associated with triplicate measures of the $\mathrm{C}(\mathrm{T})$ values for target and reference mRNA and DNA sequences was expressed as the coefficient of variation. The average coefficient of variation was calculated as a measure of variability in the $\mathrm{C}(\mathrm{T})$ values for the RNA- and DNA-based QPCR tests.

Correlation analyses among results from different diagnostic methods were carried out using $\log _{10}$-transformed data. Values equal to zero were included as $0.5 \times$ minimum detectable value for each diagnostic method.

Kudoa thyrsites infection levels, as measured by each of the 3 diagnostics, were compared with the visual assessment using the Kruskal-Wallis test to determine if there was a significant difference among means for all 6 visual categories. The KolomogorovSmirnov test was used to determine where there were significant differences in the diagnostic measure for each visual category. The p-values were calculated using the Bonferroni adjustment for multiple comparisons, and a significance level of $\mathrm{p}<0.05$ was applied.

A logistic regression analysis was used to assess whether histology, DNA QPCR, RNA QPCR, or a combination of these variables was a statistically significant predictor of the level of parasite-induced myoliquefaction.

\section{RESULTS}

\section{Sensitivity, specificity, reproducibility and reaction efficiencies of cathepsin $L$ and 18S rDNA primers}

Both RNA and DNA QPCR tests were sensitive down to 3 copies and displayed a linear quantitative range spanning 6 orders of magnitude ( 3 to $10^{6}$ copies) using cloned standards. Reaction efficiencies for the cathepsin and ARP primers, determined using relative and absolute standards, averaged $85.5 \pm 8.1 \%$ (SD) with a mean $r^{2}$ of $0.976 \pm 0.018$. Reaction efficiencies for the 18S rDNA and cytochrome B primers averaged 98.2 \pm $3.1 \%$ with a mean $\mathrm{r}^{2}$ of $0.995 \pm 0.002$. The coefficient of variation for triplicate QPCR reactions averaged $3 \%$ for the RNA-based reactions of both target and reference cDNA, and was $0.67 \%$ for the DNA-based reactions.

Primers for cathepsin L were specific for Kudoa thyrsites and did not amplify a product from DNA isolated from Myxobolus cerebralis, Kudoa minauriculata, K. hypoepicardialis, Ceratomyxa shasta, Henneguya salminicola or Sphaerospora oncorhynchi. Primers for $K$. thyrsites 18S rDNA amplified 18S rDNA from $K$. miniauriculata.

The relative cathepsin copy number for Fish 82 was calculated as $0.676 \pm 0.092( \pm \mathrm{SD})$ using a dilution series of cDNA. A similar value of $0.672 \pm 0.136$ was generated for this same sample using different amounts of RNA for cDNA synthesis.

There was a strong correlation between the relative cathepsin L mRNA copy number generated using the standard curve and the relative quantitation methods $\left(\mathrm{r}^{2}=0.999\right.$; equation $\left.y=1.0016 x-0.0045\right)$. However, because reaction efficiencies were less than $90 \%$, relative copy numbers calculated via the standard curve method were used in all other analyses (Ginzinger 2002).

The relative $18 \mathrm{~S}$ rDNA copy number in 14 samples determined on 2 different days were highly correlated $\left(\mathrm{r}^{2}=1.0\right.$; equation $\left.y=1.19 x-0.001\right)$. The relative $18 \mathrm{~S}$ rDNA copy number was also determined for 2 different samples using 6 different concentrations of starting DNA. The mean copy numbers were $8.26 \times 10^{-4} \pm$ $2.64 \times 10^{-4}$ and $0.53 \pm 0.04( \pm \mathrm{SD})$.

\section{Evaluation of different diagnostic methods}

$$
\text { Intrafish variability }
$$

Nine of 12 fish selected for assessment of intrafish variability were positive for Kudoa thyrsites by histological assessment (Table 2). RNA and DNA QPCR indicated that all 12 fish were infected with $K$. thyrsites. However, when infection levels were either undetectable or very low via histological methods, a proportion of the 9 intrafish samples were negative by QPCR (Table 2). DNA QPCR found $87 \%$ of all intrafish samples $(\mathrm{n}=107)$ positive for $K$. thyrsites, compared with $60 \%$ by RNA QPCR ( $=105)$ (Table 2 ).

All 3 diagnostic tests displayed a high degree of intrafish variation, as evidenced by the large standard deviations associated with mean infection levels for each fish (Table 2). The intrafish variation observed with all 3 diagnostic tests appeared to be completely random, i.e. there was no obvious bias towards infections occurring in a particular area (data not shown). The intrafish variation was greater for the RNA-based test than the DNA-based test and was found to vary over 5 orders of magnitude for 3 of the 12 fish tested (data not shown).

Despite this intrafish variability, correlation analyses using data from all the individual samples found that the 3 diagnostic tests generated data that were highly correlated $\left(r^{2}>0.59\right)$ (Table 3$)$. The $r^{2}$ value for each comparison increased when the data from multiple intrafish samples were averaged and then correlated. 
Table 2. Salmo salar. Average Kudoa thyrsites infection levels calculated from multiple intrafish samples determined using $\mathrm{n}=36, \mathrm{n}=107, \mathrm{n}=105$ for histology, DNA QPCR and RNA QPCR, respectively

\begin{tabular}{|c|c|c|c|c|c|c|c|c|c|c|}
\hline \multirow{2}{*}{$\begin{array}{l}\text { Fish } \\
\text { no. }\end{array}$} & \multicolumn{4}{|c|}{ — Histology } & \multicolumn{3}{|c|}{$-\log _{10}$ DNA QPCR } & \multicolumn{3}{|c|}{$-\log _{10}$ RNA QPCR } \\
\hline & $\begin{array}{c}\text { Avg. } \\
\text { histology }\end{array}$ & $\mathrm{SD}$ & $\begin{array}{l}\text { Total no. } \\
\text { plasmodia } \\
\text { counted }^{\mathrm{b}}\end{array}$ & $\begin{array}{l}\text { No. tissue } \\
\text { blocks } \\
(+) \text { ve }\end{array}$ & $\begin{array}{l}\text { Avg. } \log _{10} \\
\text { DNA } \\
\text { QPCR }^{\mathrm{c}}\end{array}$ & $\mathrm{SD}$ & $\begin{array}{l}\text { No. } \\
\text { plugs } \\
(+) \text { ve }\end{array}$ & $\begin{array}{l}\text { Avg. } \log _{10} \\
\text { RNA } \\
\text { QPCR }^{\mathrm{d}}\end{array}$ & $\mathrm{SD}$ & $\begin{array}{l}\text { No. } \\
\text { plugs } \\
\text { (+)ve }\end{array}$ \\
\hline 1 & 0.007 & 0.015 & 2 & $2 / 3$ & -5.63 & 1.50 & $5 / 9$ & -6.506 & 1.725 & $1 / 9$ \\
\hline 2 & 0.171 & 0.075 & 56 & $3 / 3$ & -1.33 & 0.51 & 9/9 & -0.696 & 0.450 & 9/9 \\
\hline 3 & 0.000 & 0.000 & 0 & $0 / 3$ & -4.74 & 1.14 & $8 / 9$ & -6.362 & 1.401 & $3 / 9$ \\
\hline 4 & 0.002 & 0.006 & 1 & $1 / 3$ & -4.84 & 0.67 & $9 / 9$ & -6.791 & 0.728 & $2 / 9$ \\
\hline 6 & 0.666 & 0.200 & 245 & $3 / 3$ & -1.35 & 0.69 & $9 / 9$ & -0.819 & 0.533 & $6 / 6$ \\
\hline 10 & 0.056 & 0.085 & 16 & $1 / 3$ & -2.53 & 0.69 & $9 / 9$ & -2.721 & 2.168 & $8 / 9$ \\
\hline 22 & 1.163 & 0.777 & 404 & $3 / 3$ & -1.37 & 0.21 & $9 / 9$ & -0.590 & 1.511 & $9 / 9$ \\
\hline 49 & 0.000 & 0.000 & 0 & $0 / 3$ & -6.16 & 0.99 & $5 / 9$ & -6.804 & 0.831 & $1 / 9$ \\
\hline 79 & 0.064 & 0.059 & 36 & $3 / 3$ & -1.44 & 0.62 & $9 / 9$ & -1.059 & 0.439 & $9 / 9$ \\
\hline 80 & 0.002 & 0.007 & 1 & $1 / 3$ & -4.41 & 1.29 & $8 / 9$ & -5.333 & 2.134 & $5 / 9$ \\
\hline 85 & 0.000 & 0.000 & 0 & $0 / 3$ & -5.91 & 0.94 & $5 / 9$ & -6.484 & 0.906 & $3 / 9$ \\
\hline 99 & 0.009 & 0.016 & 4 & $2 / 3$ & -5.10 & 1.47 & $6 / 8$ & -4.753 & 1.679 & $7 / 9$ \\
\hline \multicolumn{11}{|c|}{$\begin{array}{l}{ }^{\mathrm{a}} \text { No. plasmodia } \mathrm{mm}^{-2} \\
{ }^{\mathrm{b}} \text { Total no. plasmodia counted in all fields of view } \\
\text { c } \\
\text { delative copy number of } K \text {. thyrsites } 18 \mathrm{~S} \text { rDNA } \\
{ }^{\mathrm{d}} \text { Relative copy number of } K \text { thyrsites cathepsin L }\end{array}$} \\
\hline
\end{tabular}

Table 3. Correlation analyses among 3 diagnostic methods used to quantify Kudoa thyrsites infection levels in farm-reared Salmo salar. All correlations were carried out using $\log _{10}$-transformed data; zero values were included at $0.5 \times$ minimum detectable value for each diagnostic method

\begin{tabular}{|lrr|}
\hline Comparison & $\mathrm{r}^{2}$ & $\mathrm{n}$ \\
\hline Intrafish RNA QPCR vs. histology; individual samples & 0.61 & 105 \\
Intrafish RNA QPCR vs. histology; intrafish averages & 0.78 & 12 \\
Intrafish DNA QPCR vs. histology, individual samples & 0.59 & 107 \\
Intrafish DNA QPCR vs. histology; intrafish averages & 0.89 & 12 \\
Intrafish RNA vs. DNA QPCR; individual samples & 0.80 & 105 \\
Intrafish RNA vs. DNA QPCR; intrafish averages & 0.92 & 12 \\
Group 1: interfish RNA QPCR vs. histology & 0.63 & 96 \\
Group 1: interfish DNA QPCR vs. histology & 0.24 & 86 \\
Group 1: interfish RNA vs. DNA QPCR & 0.26 & 86 \\
Group 2: RNA QPCR vs. histology & 0.75 & 150 \\
Group 2: DNA QPCR vs. histology & 0.76 & 150 \\
Group 2: RNA vs. DNA QPCR & 0.62 & 150 \\
Group 3: DNA QPCR vs. histology & 0.67 & 362 \\
\hline
\end{tabular}

Comparison of the 3 diagnostic methods

DNA QPCR diagnosed 74\% of the fish in Group 1 (60 out of 86 fish) as positive for Kudoa thyrsites infections, compared with only $30 \%$ by RNA QPCR and $26 \%$ by histology (data not shown). All methods displayed false negatives (as determined by another method finding the fish positive for $K$. thyrsites). RNA QPCR and histology data from fish in Group 1 were not significantly correlated to DNA QPCR data $\left(\mathrm{r}^{2}=0.25\right)$ but they were significantly correlated with each other $\left(r^{2}=0.63\right)$ (Table 3).

Comparison of diagnostic data from fish in Group 2 showed a strong correlation among all 3 diagnostic methods (Table 3). Kudoa thyrsites prevalence levels were much higher in this group of fish compared with fish in Group 1, with 80,84 and $100 \%$ of the fish testing positive via histology, RNA and DNA QPCR, respectively.

A third group of fish $(\mathrm{n}=362)$ was also evaluated for Kudoa thyrsites infection levels using DNA QPCR and histology as the diagnostic methods. The $K$. thyrsites prevalence levels in this group of fish were 65 and $95 \%$ via histology and DNA QPCR, respectively. Correlation analysis confirmed a significant $\mathrm{r}^{2}$ value between these 2 diagnostic methods (Table 3 ), and a regression analysis of these data generated an equation that was very similar to that of the data from fish in Group 2 (Fig. 2).

\section{Diagnostic methods as predictors of post-mortem flesh quality}

Visual evaluation of the flesh quality in fish from Group 2 found all categories to be represented by at least 13 fish. Average values from the 3 diagnostic tests that corresponded to each visual category are reported in Table 4. A logistic regression analysis comparing each diagnostic method to the visual assessment of fillet quality indicated that all methods were significant predictors of fillet quality, with $\mathrm{r}^{2}$ values of $0.82,0.73$ and 0.62 for histology, DNA QPCR and RNA QPCR, 


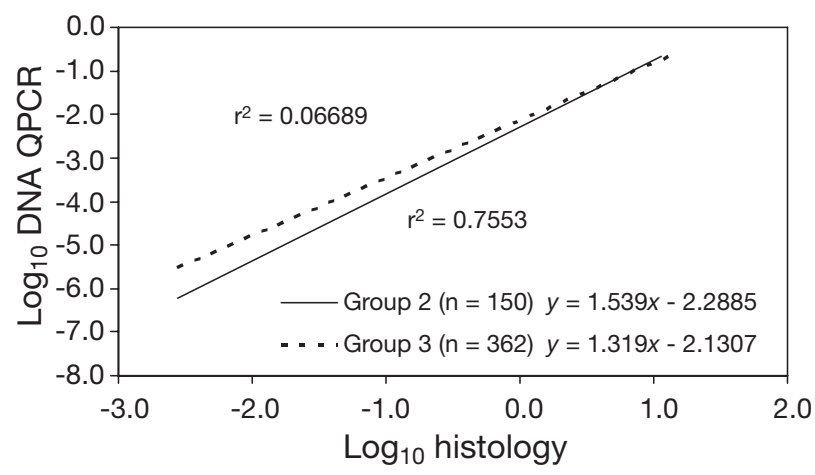

Fig. 2. Comparison of regression analyses between DNA QPCR and histology data (in no. of plasmodia $\mathrm{mm}^{-2}$ ) from fish in Groups 2 and 3

respectively. The best combination of predictors was histology and DNA QPCR $\left(\mathrm{r}^{2}=0.83\right)$. The range of diagnostic values associated with each visual category is displayed in Fig. 3, in which the cumulative percent of fish in each visual category was plotted against $\log _{10}$-transformed data for each diagnostic measure. As a predictor of flesh quality, histology was able to show significant differences among 3 consecutive visual categories ('a' in Visual Categories 1, 4 and 5 in Fig. 3A). A separation of 2 visual categories is required to meet the significance level of $\mathrm{p}<0.05$ (' $\mathrm{b}$ ' in Visual Categories 2 and 3 in Fig. 3A). In other words, the histology values associated with Visual Category 2 were not significantly different from values in Visual Category 3, but were significantly different from values in Visual Category 4. DNA QPCR was able to differentiate 2 consecutive visual categories (Fig. 3B). RNA QPCR displayed more overlap among visual categories, and there were no significant differences among Visual Categories 2, 3 and 4 (Fig. 3C).

\section{DISCUSSION}

Several methods have been developed for the quantitation of Kuoda thyrsites infections in Atlantic salmon, including histology, spore counts and ELISA (St-Hilaire et al. 1997a,b, Moran et al. 1999b, DawsonCoates et al. 2003, Taylor \& Jones 2005). Histological examination of muscle for the presence of plasmodia has been the standard technique for determining $K$. thyrsites infection levels, and this measure has been shown to correlate well with post-mortem flesh quality (Dawson-Coates et al. 2003). However, histology is labour intensive, requires multiple large pieces of tissue to provide accurate results at low infection levels and cannot be used as a reliable method for detection of plasmodia until approximately 900 degree days post-exposure (Moran et al. 1999b). A newly devel-
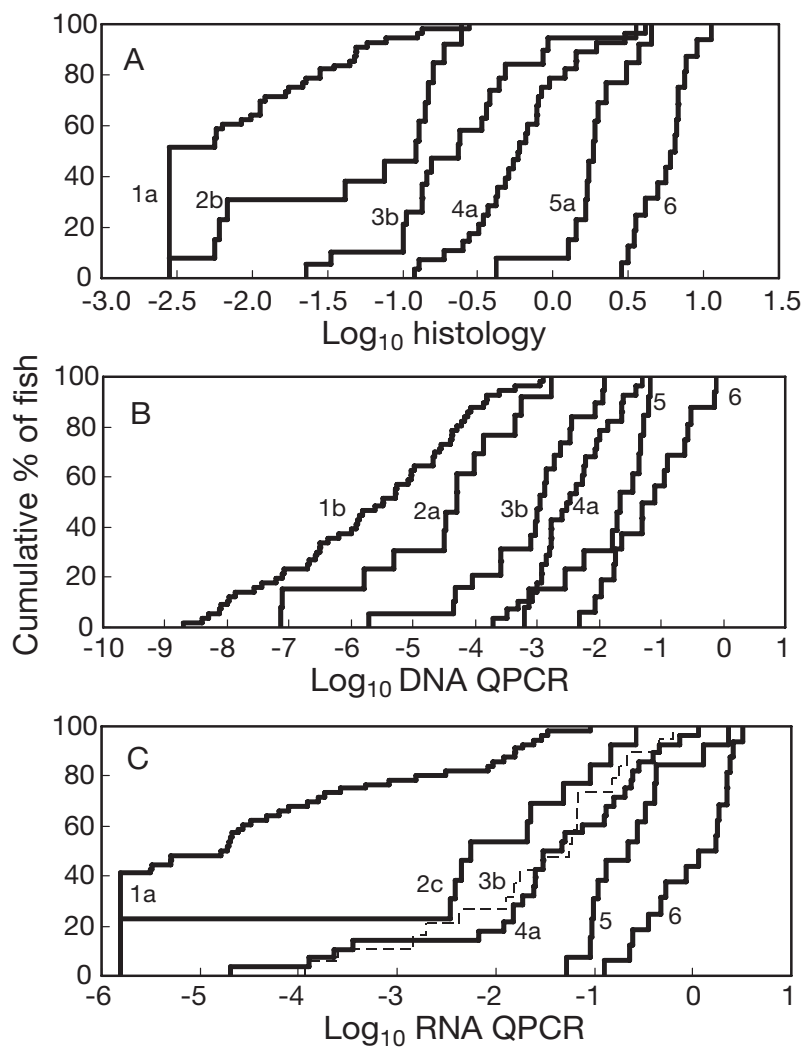

Fig. 3. Comparison of diagnostic values for each visual category of fillet quality. Flesh quality was assessed $7 \mathrm{~d}$ postmortem using an arbitrary scale (1 to 6 ) of visual categories where 1 = no damage due to Kudoa thyrsites and $6=$ extreme myoliquefaction. Fish belonging to each visual category were grouped, and diagnostic data were plotted in ascending order with the cumulative \% of fish in each visual category. Zero values were included as $0.5 \times$ minimum detectable level for each diagnostic method. (A) $\log _{10}$-transformed histology data (in no. plasmodia $\mathrm{mm}^{-2}$ ), (B) $\log _{10^{-}}$ transformed DNA QPCR data (relative copy number of $K$. thyrsites 18S rDNA), (C) $\log _{10}$ transformed RNA QPCR data (relative copy number of $K$. thyrsites cathepsin L mRNA). Dashed line indicates cumulative \% of fish in Visual Category 3. Letters indicate significant differences $(p<0.05)$ : $a=$ significant difference between consecutive visual categories; $\mathrm{b}=\mathrm{a}$ separation of 2 visual categories is required for significant difference; $\mathrm{c}=\mathrm{a}$ separation of 3 visual categories is required for significant difference

oped ELISA technique has proven to be both sensitive and accurate but is not readily available to all laboratories owing to the requirement of polyclonal antiserum (Taylor \& Jones 2005).

QPCR is rapidly replacing traditional diagnostics as the method of choice owing to its sensitivity, specificity, decreased labour, and increased sample throughput as well as its availability and reproducibility among laboratories. QPCR assays have already been successfully developed for the following fish pathogens: Piscirickettsia salmonis, infectious haematopoietic necrosis virus, Edwardsiella ictaturi, Flavo- 
Table 4. Average values from the 3 diagnostic tests that correspond to each visual category (for details of categories see Fig. 3)

\begin{tabular}{|c|c|c|c|c|}
\hline $\begin{array}{l}\text { Visual } \\
\text { category }\end{array}$ & $\mathrm{n}$ & $\begin{array}{l}\text { Histology } \\
\pm \mathrm{SD}^{\mathrm{a}}\end{array}$ & $\begin{array}{c}\log _{10} \text { DNA QPCR } \\
\pm \mathrm{SD}^{\mathrm{b}}\end{array}$ & $\begin{array}{c}\log _{10} \text { RNA QPCR } \\
\pm \mathrm{SD}^{\mathrm{c}}\end{array}$ \\
\hline 1 & 56 & $0.022 \pm 0.044$ & $-5.67 \pm 1.53$ & $-4.44 \pm 1.56$ \\
\hline 2 & 13 & $0.098 \pm 0.081$ & $-4.63 \pm 1.37$ & $-2.61 \pm 1.92$ \\
\hline 3 & 19 & $0.46 \pm 0.79$ & $-3.14 \pm 0.95$ & $-1.64 \pm 1.04$ \\
\hline 4 & 28 & $0.92 \pm 0.91$ & $-2.43 \pm 0.63$ & $-1.52 \pm 1.17$ \\
\hline 5 & 13 & $2.10 \pm 1.12$ & $-1.87 \pm 0.74$ & $-0.63 \pm 0.49$ \\
\hline 6 & 16 & $5.97 \pm 2.29$ & $-1.19 \pm 0.69$ & $-0.03 \pm 0.44$ \\
\hline \multicolumn{5}{|c|}{$\begin{array}{l}{ }^{\mathrm{a}} \text { No. of plasmodia } \mathrm{mm}^{-2} \\
\text { belative copy number of Kudoa thyrsites } 18 \mathrm{~S} \text { rDNA } \\
\text { c Relative copy number of } K \text {. thyrsites cathepsin L mRNA }\end{array}$} \\
\hline
\end{tabular}

epicardialis (Blaylock et al. 2004). There was only 1 mismatch in the reverse primer for $K$. miniauriculata $18 \mathrm{~S}$ rDNA, whereas $K$. hypoepicardialis 18S rDNA differed at 10 sites. These results were not unexpected because analyses of the 18S rDNA sequences consistently clustered $K$. thyrsites and $K$. miniauriculata together, while $K$. hypoepicardialis was more divergent, showing only $91.9 \%$ sequence identity to $K$. thyrsites compared with $96.3 \%$ between $K$. miniauriculata and $K$. thyrsites (Kent et al. 2001, Blaylock et al. 2004, Whipps et al. 2004).

Significant intrafish variability was observed for all 3 diagnostic methods, indi-

bacterium psychrophilum and Myxobolus cerebralis (Overturf et al. 2001, del Cerro et al. 2002, Bilodeau et al. 2003, Corbeil et al. 2003, Cavender et al. 2004, Kelley et al. 2004). While the DNA approach has proven accurate in providing a measure of pathogen infection levels, it does not provide insight into gene expression patterns during growth and development of the pathogen or shed light on the biological mechanisms responsible for disease. The present study developed not only a standard DNA-based QPCR test for Kudoa thyrsites that targeted 18S rDNA (Hervio et al. 1997), but also an RNA-based test that targeted cathepsin L mRNA whose translated product may be largely responsible for the post-mortem myoliquefaction of host muscle tissue characteristic of $K$. thyrsites infections (V. Funk et al. unpubl. data).

The RNA QPCR test showed more variation among replicate samples than did the DNA QPCR test, as reflected by the higher coefficient of variation. The reaction efficiencies were also lower for the RNA-based test than for the DNA-based test. Reaction efficiencies of the RNA QPCR test using the cathepsin L primers and probes averaged $85 \%$, which is slightly lower than the recommended $90 \%$ for use of the relative quantitation method of $2^{-\Delta \mathrm{C}(\mathrm{T})}$ (Ginzinger 2002); yet, a correlation analysis comparing these values to those obtained using the standard curve method gave an $\mathrm{r}^{2}$ of 0.999 . Clearly, deviations in efficiencies observed in this study did not have a significant effect on the relative copy number calculated by the 2 methods.

Cathepsin L primers did not cross-react with the other species tested, suggesting either sequence variability or the absence of a homologous protein in the species tested. However, 18S rDNA primers crossreacted with $18 \mathrm{~S}$ rDNA from Kudoa miniauriculata. Analysis of $18 \mathrm{~S}$ rDNA sequences showed that the forward primer used to amplify $K$. thyrsites $18 \mathrm{~S}$ rDNA differed from $K$. miniauriculata $18 \mathrm{~S}$ rDNA at only 3 sites, but showed 9 mismatches for this gene in K. hypo- cating that Kudoa thyrsites plasmodia were not evenly distributed throughout fish musculature. This biological variability observed within a fish confirms the need for multiple intrafish samples in order to improve data accuracy, as illustrated by the improved $\mathrm{r}^{2}$ values when correlating intrafish averages as opposed to data from single, discrete samples. However, significant correlations were still observed among all diagnostic methods when using data from single, discrete samples. This provided compelling evidence that all 3 diagnostic tests were accurate in quantifying $K$. thyrsites infection levels. Accuracy of the tests and sufficient sampling regimens were further supported by significant correlations occurring among all diagnostic methods when comparing data from fish in Groups 2 and 3.

The process of validating new diagnostic tests in the absence of a perfect definitive test is difficult. There is no definitive test for Kudoa thyrsites or for other pathogens such as Myxobolus cerebralis and Toxoplasma spp., which can be present at low levels and with unpredictable distribution patterns, so that the accuracy of a diagnostic method is linked to test sensitivity, the abundance of the target used for detection and the sampling regimen (Esteban-Redondo et al. 1999, Jauregui et al. 2001, Dawson-Coates et al. 2003, Cavender et al. 2004, Taylor \& Jones 2005). Evidence was reported herein demonstrating that all 3 diagnostic tests, coupled to the sampling regimens, accurately quantified $K$. thyrsites infection levels. However, the minimum infection level that each method was capable of detecting differed. DNA QPCR was capable of detecting lower $K$. thyrsites infection levels than RNA QPCR and histology.

In attempting to understand the higher threshold for detection of Kudoa thyrsites via RNA QPCR, it is important to acknowledge that RNA and DNA were extracted from the same piece of tissue for fish in Group 1. It is also important to acknowledge that both RNA- and DNA-based tests displayed the same detec- 
tion limit of 3 copies when using clone standards. Therefore, the lower number of fish in Group 1 diagnosed with $K$. thyrsites via RNA QPCR compared with DNA QPCR was not a result of the sampling regimen or a limitation of the diagnostic method, but was likely a result of biological differences in the amount of cathepsin L mRNA compared with 18S rDNA.

However, the amount of cathepsin L mRNA compared with the amount of 18S rDNA was not always the same. Data from fish in Group 1 showed that if cathepsin L mRNA was detected, then the relative amount of this target was similar to the relative amount of $18 \mathrm{~S}$ rDNA. Conversely, data from fish in Group 2 revealed that the relative amount of cathepsin $\mathrm{L}$ mRNA was typically greater than the relative amount of $18 \mathrm{~S}$ rDNA. These results suggest that expression of cathepsin L was not consistent among plasmodia. It may be significant that fish in Group 1 had been exposed to sea water for only 1200 degree days compared with 2600 degree days for fish in Group 2, suggesting that expression of cathepsin L does not occur during early life stages of the plasmodia. It is probable that the cathepsin $\mathrm{L}$ peptidase functions to facilitate spore release into the environment for completion of the life cycle by liquefying host muscle tissue. Therefore, expression of the cathepsin L gene may not occur until mature myxospores have developed-a process requiring approximately 1000 degree days (Moran \& Kent 1999). Such a developmental delay in expression of cathepsin L would contribute to the different levels of $18 \mathrm{~S}$ rDNA and cathepsin L mRNA in fish from Groups 1 and 2. Alternatively, the higher levels of RNA compared with DNA observed for fish in Group 2 could represent a sampling bias owing to the fact that RNA and DNA were extracted from different muscle samples. However, the consistently higher levels of mRNA compared with 18S rDNA would suggest a real biological difference. Additional work will be required to determine if expression of the cathepsin L gene is developmentally regulated.

The sensitivity of histology as a diagnostic measure was similar to that of RNA QPCR and significantly lower than that of DNA QPCR. The amount of muscle cross-sectional area observed for the histological detection of Kudoa thyrsites plasmodia in Group 1 fish averaged $435 \mathrm{~mm}^{2}, 3$ times that observed in previous studies (Dawson-Coates et al. 2003, Taylor \& Jones 2005) and over twice that observed for the assessment of fish in Groups 2 and 3 in the present study. This surface area represents 9 thin section measuring $7 \times$ $7 \mathrm{~mm}$, and yet this increased effort resulted in only $27 \%$ of fish in Group 1 being identified as positive for K. thyrsites compared with $74 \%$ diagnosed as positive using the DNA QPCR test. With the added histological effort, it was surprising that the sensitivity of this method was so low compared with DNA QPCR, which used less than $100 \mathrm{mg}$ of muscle tissue. The increased sensitivity of DNA QPCR compared with histology may be partially attributed to the fact that $18 \mathrm{~S}$ rDNA can be detected via PCR long before the plasmodia reach a size that can be observed in histological thin sections. These data clearly indicated that histology has a limited sensitivity compared with DNA QPCR, which cannot be overcome by increased sampling regimens.

The 3 diagnostic methods were also evaluated for their ability to predict post-mortem flesh quality. The results indicated that histology was the single best predictor of post-mortem flesh quality and DNA QPCR the second best predictor. From the practical perspective of a salmon producer, it was interesting that histology was the best predictor of flesh quality because this indicated that if the Kudoa thyrsites infection level was below the level of detection via histology, then the producer will not have a problem with flesh quality. A visual category of 3 represents the level of deterioration or myoliquefaction that would make it difficult for the producer to sell their product. The average diagnostic values associated with this visual category were -3.14 and -1.64 for $\log _{10}$-transformed data for the relative copy number of $18 \mathrm{~S}$ rDNA (DNA QPCR) and cathepsin L mRNA (RNA QPCR), respectively, and 0.4 plasmodia $\mathrm{mm}^{-2}$ for histology. It was interesting that the value of 0.4 plasmodia $\mathrm{mm}^{-2}$ calculated in this study as a threshold for flesh quality problems was very similar to the value of 0.3 plasmodia $\mathrm{mm}^{-2}$ previously predicted to cause significant fillet damage (Dawson-Coates et al. 2003). The consistency of these results again indicates that histology is an accurate and reproducible measure of $K$. thyrsites infection levels, and validates its use in the development of new diagnostic tests.

This study was undertaken primarily to develop a sensitive and quantitative method of measuring Kudoa thyrsites infection levels so that the effect of experimental treatments, such as a vaccine, could be measured accurately and after shorter sea water exposure periods than required when using histology as the diagnostic method. DNA QPCR proved to be the method of choice for this application owing to its superior sensitivity when using less than $100 \mathrm{mg}$ of muscle tissue. As such, this new test represents a significant research tool that is readily transferred among laboratories, is less labour intensive and allows increased sample throughput compared with other diagnostic techniques.

This study also improved our confidence in all available diagnostic methods, including the visual evaluation of fillets, because all methods were significantly correlated. Therefore, if the objective is simply to evaluate Kudoa thyrsites infection levels within a popula- 
tion to determine if there will be flesh quality problems in the market place, then the farmer can choose histology, DNA QPCR or visual evaluation depending on the expertise available.

The RNA QPCR test proved to be of limited value as a diagnostic test owing to its reduced sensitivity compared with DNA QPCR, and lower correlation values when comparing data from the RNA-based test with data from the other diagnostic methods. However, the RNA-based test will be used to investigate gene expression patterns in the parasite, thus providing the first information on the biology of the plasmodia within host myocytes and on mechanisms regulating postmortem myoliquefaction.

Acknowledgements. Thanks to Dr. C. M. Whipps, Oregon State University, for DNA from several myxosporeans. Special thanks to the Aquaculture Collaborative Research Development Program and Pan Fish Canada for funding this research.

\section{LITERATURE CITED}

Bilodeau AL, Waldbieser GC, Terhune JS, Wise DJ, Wolters WR (2003) A real-time polymerase chain reaction assay of the bacterium Edwardsiella ictaluri in channel catfish. J Aquat Anim Health 15:80-86

Blaylock RB, Bullard SA, Whipps CM (2004) Kudoa hypoepicardialis n. sp. (Myxozoa: Kudoidae) and associated lesions from the heart of seven perciform fishes in the northern Gulf of Mexico. J Parasitol 90:584-593

Cavender WP, Wood JS, Powell MS, Overturf K, Cain KD (2004) Real-time quantitative polymerase chain reaction (QPCR) to identify Myxobolous cerebralis in rainbow trout Oncorhynchus mykiss. Dis Aquat Org 60:205-213

Corbeil S, McColl KA, Crane MStJ (2003) Development of a TaqMan quantitative PCR assay for the identification of Piscirickettsia salmonis. Bull Eur AssOC Fish Pathol 23: 95-101

Dawson-Coates JA, Chase JC, Funk V, Booy MH and 5 others (2003) The relationship between flesh quality and numbers of Kudoa thyrsites plasmodia and spores in farmed Atlantic salmon, Salmo salar L. J Fish Dis 26:451-459

del Cerro A, Mendoza MC, Guijarro JA (2002) Usefulness of a TaqMan-based polymerase chain reaction assay for the detection of the fish pathogen Flavobacterium psychrophilum. J Appl Microbiol 93:149-156

Esteban-Redondo L, Maley SW, Thompson K, Nicoll S, Wright S, Buxton D, Innes EA (1999) Detection of T. gondii in tissues of sheep and cattle following oral infection. Vet Parasitol 86:155-171

Funk VA, Jones SRM, Kim E, Kreiberg H, Taylor K, Wu S, Young $C$ (2004) The effect of vaccination and sea water entry on immunocompetence and susceptibility to Kudoa thyrsites in Atlantic salmon (Salmo salar L.). Fish Shellfish Immunol 17:375-387

Ginzinger DG (2002) Gene quantification using real-time quantitative PCR: an emerging technology hits the mainstream. Exp Hematol 30:503-512

Hervio DML, Kent ML, Khattra J, Sakanari J, Yokoyama H, Devlin RH (1997) Taxonomy of Kudoa species (Myxosporea), using a small-subunit ribosomal DNA sequence. Can J Zool 75:2112-2119

Hillis DM, Dixon MT (1991) Ribosomal DNA: molecular evo-

Editorial responsibility: Robin Overstreet,

Ocean Springs, Mississippi, USA lution and phylognentic inference. Quart Rev Biol 66: 411-453

Jauregui LH, Higgins J, Zarlenga D, Dubey JP, Lunney JK (2001) Development of a real-time PCR assay for detection of Toxoplasma gondii in pig and mouse tissues. J Clin Microbiol 39:2065-2071

Kelley GO, Zagmutt-Vergara FJ, Leutenegger CM, Myklebust KA and 7 others (2004) Evaluation of five diagnostic methods for the detection and quantification of Myxobolus cerebralis. J Vet Diagn Invest 16:202-211

Kent ML, Khattra J, Hefick RP, Devlin RH (2000) Tetracapsula renicola N. sp. (Myxozoa: Saccosporidae); the PKX myxozoan - the cause of proliferative kidney disease of salmonid fishes. J Parasitol 86:103-111

Kent ML, Andree KB, Bartholomew JL, El-Matbouli M and 12 others (2001) Recent advance in our knowledge of the Myxozoa. J Eukaryot Microbiol 48:395-413

Moran JDW, Kent ML (1999) Kudoa thyrsites (Myxozoa: Myxosporea) infections in pen-reared Atlantic salmon in the northeast Pacific ocean with a survey of potential nonsalmonid reservoir hosts. J Aquatic Anim Health 11:101-109

Moran JDW, Whitaker KJ, Kent ML (1999a) A review of the myxoporean genus Kudoa Meglitsch, 1947, and its impact on the international aquaculture industry and commercial fiseries. Aquaculture 172:163-196

Moran JDW, Margolis L, Webster JM, Kent ML (1999b) Development of Kudoa thyrsites (Myxozoa: Myxosporea) in netpen-reared Atlantic salmon determined by light microscopy and a polymerase chain reaction test. Dis Aquat Org 37:185-193

Overturf K, LaPatra S, Powell M (2001) Real-time PCR for the detection and quantitative analysis of IHNV in salmonids. J Fish Dis 24:325-333

Pierce AL, Dickey JT, Larsen DL, Fukada H, Swanson P, Dickhoff WW (2004) A quantitative real-time RT-PCR assay for salmon IGF-1 mRNA and its application in the study of GH regulation of IGF-1 gene expression in primary culture of salmon hepatocytes. Gen Comp Endocrinol 135:401-411

Purcell MK, Kurath G, Garver KA, Herwig RP, Winton JR (2004) Quantitative expression profiling of immune response genes in rainbow trout following infectious haematopoietic necrosis virus (IHNV) infection or DNA vaccination. Fish Shellfish Immunol 17:447-462

St-Hilaire S, Hill M, Kent ML, Whitaker DJ, Ribble C (1997a) A comparative study of muscle texture and intensity of Kudoa thyrsites infection in farm-reared Atlantic salmon Salmo salar on the Pacific coast of Canada. Dis Aquat Org 31:221-225

St-Hilaire S, Ribble C, Whitaker DJ, Kent ML (1997b) Evaluation of a non-destructive diagnostic test for Kudoa thyrsites in farmed Atlantic salmon (Salmo salar). Aquaculture 156:139-144

Taylor K, Jones SRM (2005) An enzyme-linked immunosorbent assay for the detection of Kudoa thyrsites in Atlantic salmon Salmo salar. Aquaculture 250:8-15

Whipps CM, Grossel G, Adlard RD, Yokoyama H, Bryant MS, Munday BL, Kent ML (2004) Phylogeny of the multivalvulidae (Myxozoa:Myxosporea) based on comparative ribosomal DNA sequence analysis. J Parasitol 90:618-622

Wolf K, Markiw ME (1984) Biology contravenes taxonomy in the Myxozoa: new discoveries show alternation of invertebrate and vertebrate hosts. Science 225:1449-1452

Yin LJ, Shackel NA, Zekry A, McGuinness PH and 5 others (2001) Real-time reverse transcriptase-polymerase chain reaction (RT-PCR) for measurement of cytokine and growth factor mRNA expression with fluorogeneic probes or SYBER Green. J Immunol Cell Biol 79:213-221

Submitted: September 4, 2006; Accepted: December 29, 2006 Proofs received from author(s): March 15, 2007 